\title{
Efektifitas Pijat Bayi terhadap Peningkatan Berat Badan, Lama Waktu Tidur dan Kelancaran Buang Air Besar
}

\author{
The Effectiveness of Baby Massage Against Increased Weight, Long sleep Time and \\ Smooth Bowel Movements \\ Sadiman Sadiman ${ }^{1 凶}$, Islamiyati Islamiyati ${ }^{1}$ \\ ${ }^{1}$ Program Studi Kebidanan Metro, Politeknik Kesehatan Tanjungkarang, Indonesia \\ Corresponding author: *sadiman@poltekkes-tjk.ac.id
}

Kata kunci:

Pijat bayi;

Peningkatan $B B$;

Waktu tidur;

Kelancaran $B A B$.
Keyword:

Baby massage;

Increase in body weight;

Bedtime;

Smooth bowel

movements.

\begin{abstract}
Abstrak
Latar Belakang: Pijat bayi sebagai salah satu bentuk bahasa sentuhan ternyata memiliki efek yang positif untuk pertumbuhan dan perkembangan bayi. Pelaksanaan pijat bayi oleh dukun bayi banyak yang tidak sesuai dengan teknik pijat bayi yang terdapat dalam pedoman pijat bayi menurut kesehatan. Dalam rangka meningkatkan sentuhan fisik seperti belaian, pelukan dan pijatan lembut yang akan meningkatkan ikatan kasih sayang antara ibu dan bayi, namun para ibu sendiri tidak melakukan karena tidak memahami teknik pijat bayi tersebut. Tujuan: mengetahui efektifitas pijat bayi terhadap peningkatan berat badan, lama waktu tidur dan kelancaran buang air besar. Metode: Penelitian menggunakan quasi experiment non equivalen control group design. Sampel 46 ibu dengan bayinya diambil dengan teknik simple random sampling. Analisis data dengan dependen sampel $t$ tes dan independen sampel $t$ test. Hasil: Rata-rata berat badan bayi sebelum dan sesudah dilakukan pemijatan pada kelompok perlakuan dengan $p$ value 0,000 dan pada kelompok kontrol dengan $\mathrm{p}$ value 0,000 . Rata-rata waktu tidur bayi dengan $p$ value 0,000 dan pada kelompok kontrol dengan $p$ value 0,030 . Rata-rata frekuensi BAB bayi sebelum dan sesudah dilakukan pemijatan pada kelompok perlakuan dengan $p$ value 0,025 dan kelompok kontrol dengan $p$ value 0,655. Simpulan: Pijat bayi efektif untuk meningkatkan rata-rata berat badan bayi, rata-rata waktu tidur bayi, dan rata-rata frekuensi BAB bayi.
\end{abstract}

\begin{abstract}
Background: Baby massage as one form of touch language turned out to have positive effect for baby growth and development. Implementation of baby massage by shamans massage Baby many who do not comply with the technique of baby massage contained in the of baby massage according to health. In order to improve the physical touch such as caresses, hugs and gentle massage that will increase the bond of affection between mother and baby, but the mothers themselves Not do because it does not understand the baby massage technique. Purpose: To know the effectiveness of baby massage against increased weight, long sleep and smooth bowel movements. Methods: Draft research quasi experiment non equivalent control group design. Sample 44 mother with her baby taken with simple random sampling technique. Analyze the data with dependent T sample test and independent sample T test. Results: The weight increase before and after the massage in the treatment group with $P$ value 0.000 and in the control group with $P$ value 0.000 . Analysis of the average increase in baby sleep time by $P$ value 0.000 and in the control group with $P$ value 0.030. The average in the frequency of the infant's bowel movements before and after massage in the treatment group with $P$ value 0.025 and control group with P value 0.655. Conclusion: Infant massage is effective for increasing the average weight of the baby, the average sleep time of the baby, and the average frequency of bowel movements in infants.
\end{abstract}

Copyright (C) 2019 Jurnal Kesehatan Metro Sai Wawai. All rights reserved. 


\section{Pendahuluan}

Penyebab kematian neonatal tertinggi di Provinsi Lampung pada tahun 2012 adalah BBLR sebesar 32\% dan infeksi sebesar 18\% (Dinkes Provinsi Lampung, 2013). Kenaikan berat badan bayi baru lahir dengan BBLR dapat ditingkatkan salah satunya dengan pijat bayi. Berbagai penyakit infeksi dapat dicegah dengan meningkatkan imunitas bayi melalui pijat bayi yang dapat merangsang nafsu makan bayi sehingga bayi akan menghisap ASI lebih banyak yang akan mengoptimalkan pemenuhan kebutuhan gizi bayi. Pijat bayi sebaiknya dilakukan oleh orang yang terdekat dengan bayi dalam hal ini ibu bayi dalam rangka meningkatkan sentuhan fisik seperti belaian, pelukan dan pijatan lembut yang akan meningkatkan ikatan kasih sayang antara ibu dan bayi. Bayi yang dipijat akan mengalami peningkatan tonus nervus vagus (saraf otak ke 10) yang membuat kadar enzim penyerapan gastrin dan insulin meningkat sehingga penyerapan sari makanan menjadi lebih baik, penyerapan makanan yang lebih baik akan menyebabkan bayi cepat lapar dan karena itu bayi akan lebih sering menyusu (Roesli, 2011; Pratyahara, 2012).

Sampai saat ini masih ada orang tua yang menganggap pijat bukanlah sebuah bentuk terapi ilmiah sekaligus alamiah bagi bayi. Namun fakta menyebutkan bahwa pijat merupakan metode terapi sentuh tertua di Indonesia. Para ahli kesehatan menemukan pijatan dengan teknik yang tepat kepada anak dan balita, bisa dilakukan saat mereka dalam kondisi kesehatan yang baik (Maharani, 2009). Berdasarkan informasi pendahuluan yang didapatkan penulis bahwa belum ada ibu di wilayah Puskesmas Punggur yang melakukan pijat terhadap bayinya yang sesuai dengan pedoman pijat menurut kesehatan. Jikapun ada bayi yang dipijat, hal ini dilakukan oleh dukun bayi. Data yang didapatkan dari Laporan bulanan Puskesmas Punggur sejak Januari - April 2015 didapatkan bahwa rata-rata bayi yang tidak naik berat badan sebesar $11,1 \%$. Selanjutnya didapatkan juga bahwa ada sebesar $4,4 \%$ bayi mengalami diare. Lamanya tidur sebagian $(50 \%)$ bayi dikeluhkan mengalami gangguan waktu tidur, hal ini dikarenakan bayi mengalami batuk, pilek dan suhu badan yang panas, (Puskesmas Punggur, 2015).

\section{Metode}

Penelitian ini merupakan penelitian quasi experiment dengan rancangan non equivalen control group design. Rancangan non equivalen control group design, yaitu suatu penelitian eksperimen yang dilakukan dengan cara memilih 2 kelompok studi yaitu kelompok perlakukan dan kelompok kontrol) tetapi tidak dilakukan randomisasi. Baik kelompok perlakuan dan kelompok kontrol semuanya diberikan pre test untuk mengetahui keadaan awal dan selanjutnya dilakukan post test untuk melihat efek dari perlakuan yang diberikan. Populasi penelitian ini adalah ibu yang mempunyai bayi dengan umur 3 bulan sampai 6 bulan pada bulan Mei 2015 di wilayah Puskesmas Punggur Kabupaten Lampung Tengah sebanyak 150 orang. Sampel diambil sebagian dari populasi yang dihitung dengan rumus penghitungan sampel intervensi perbedaan dua mean (Lemeshow, 2000) diperoleh jumlah sampel minimal 44 orang, yaitu 22 kelompok perlakuan dan 22 orang lagi sebagai kelompok control. Pada penelitian ini sampel sebanyak 46 orang, yaitu 23 kelompok perlakuan dan 23 orang lagi sebagai kelompok kontrol. Teknik pengambilan sampel akan dilakukan dengan Simple Random Sampling.

Penelitian dilaksanakan di wilayah Puskesmas Punggur Kabupaten Lampung Tengah, pada bulan Agustus sampai September 2015. Subjek penelitian yang memenuhi kriteria sebanyak 46 orang dibagi menjadi kelompok perlakuan 23 orang yang dipijat setiap hari dan kelompok kontrol 23 orang yang dipijat seperti biasa dengan dukun bayi. Subjek penelitian baik pada kelompok perlakuan dan kelompok kontrol dilakukan pretest dengan cara menimbang berat badan, melakukan wawancara ibu tentang lama waktu tidur bayi dan frekuensi buang air besar. Selanjutnya dilakukan pelatihan pijat bayi pada kelompok perlakuan mengharuskan kelompok perlakuan melakukan pemijatan pada bayinya rutin selama 1 bulan dengan waktu minimal 15 menit. Jarak waktu satu bulan kemudian 
kelompok perlakuan dan kelompok kontrol dilakukan postest dengan cara menimbang berat badan, mewawancarai ibu tentang lama waktu tidur bayi dan frekuensi buang air besar. Analisis data dengan dependen sampel $t$ tes dan independen sampel $t$ test. Pertimbangan kaji etik (ethical clearance) penelitian diperoleh dari Komisi Etik Politeknik Kesehatan Tanjung Karang.

\section{Hasil}

Rata-rata berat badan bayi, lama waktu tidur dan kelancaran BAB sebelum dan sesudah pijat bayi pada kelompok perlakuan dan kontrol

Pada tabel 1 diketahui bahwa pada kelompok perlakuan rata-rata berat badan bayi meningkat dari 6.673,9 gram menjadi 7.195,7 gram. Pada kelompok kontrol rata-rata berat badan bayi meningkat dari 6.956,5 gram menjadi 7.310,9 gram. Lama waktu tidur pada kelompok perlakuan meningkat dari 662,7 menit menjadi 743,4 menit. Pada kelompok kontrol menurun dari 693,7 menit menjadi 639,8 menit. Kelancaran BAB pada kelompok perlakuan 5 orang bayi yang tidak normal menjadi semua bayi normal dalam kelancaran BAB. Pada kelompok kontrol 4 orang bayi yang tidak normal dalam kelancaran $\mathrm{BAB}$ menjadi 3 orang bayi yang tidak normal dalam kelancaran $\mathrm{BAB}$.

Tabel 1.

Rata-rata berat badan bayi, lama waktu tidur dan kelancaran BAB pada kelompok perlakuan dan kontrol

\begin{tabular}{lcccc}
\hline \multirow{2}{*}{ Kelompok Variabel } & \multicolumn{2}{c}{ Mean } & Sebelum & Sesudah \\
\cline { 2 - 5 } Berat Badan bayi & Sebelum & Sesudah & & \\
$\quad$ Kelompok Perlakuan & 6673,9 & 7195,7 & 1060,1 & 935,4 \\
Kelompok Kontrol & 6956,5 & 7310,9 & 969,5 & 850,9 \\
Lama waktu tidur & & & & \\
Kelompok Perlakuan & 662,7 & 743,4 & 106,9 & 108,6 \\
Kelompok Kontrol & 693,7 & 639,8 & 97,6 & 143,9 \\
Kelancaran BAB & & & & \\
Kelompok Perlakuan & 18 & 78,3 & 23 & 100 \\
Normal & 5 & 21,7 & 0 & 0 \\
Tidak Normal & & & & \\
Kelompok Kontrol & 19 & 82.6 & 20 & 87.0 \\
Normal & 4 & 17.4 & 3 & 13.0 \\
Tidak Normal & 23 & 100 & 23 & 100 \\
$\quad$ Jumlah & & & & \\
\hline
\end{tabular}

\section{Efek Pijat Bayi terhadap Peningkatan BB Bayi}

Berdasarkan tabel 2 diketahui bahwa ada perbedaan rata-rata berat badan bayi sebelum dan sesudah dilakukan pemijatan pada kelompok perlakuan dengan $p$ value 0,000 . Pada kelompok kontrol juga ada perbedaan rata-rata berat badan bayi sebelum dan sesudah dilakukan pemijatan dengan $\mathrm{p}$ value 0,000 . Ada perbedaan rata-rata waktu tidur bayi sebelum dan sesudah dilakukan pemijatan pada kelompok perlakuan dengan $\mathrm{p}$ value 0,000 . Pada kelompok kontrol juga ada perbedaan rata-rata waktu tidur bayi sebelum dan sesudah dilakukan pemijatan pada kelompok perlakuan dengan $p$ value 0,030 .

\section{Efek Pijat Bayi terhadap Kelancaran frekuensi BAB}

Berdasarkan tabel 3 diketahui bahwa ada perbedaan rata-rata frekuensi BAB bayi sebelum dan sesudah dilakukan pemijatan pada kelompok perlakuan dengan $p$ value 0,025 . Pada kelompok kontrol tidak ada perbedaan rata-rata frekuensi BAB bayi sebelum dan sesudah dilakukan pemijatan dengan $\mathrm{p}$ value 0,655 . 
Tabel 2

Perbedaan rata-rata berat badan Bayi dan lama waktu tidur pada kelompok perlakuan dan kontrol

\begin{tabular}{lccc}
\hline Kelompok & Mean & SD & p-value \\
\hline Berat Badan bayi & & & \\
Kelompok Perlakuan & -488.043 & 437.567 & 0,000 \\
Kelompok Kontrol & -315.217 & 340.266 & 0,000 \\
Lama waktu tidur & & & \\
Kelompok Perlakuan & -80.652 & 88.664 & 0,000 \\
Kelompok Kontrol & 53.913 & 111.685 & 0,030 \\
\hline
\end{tabular}

Tabel 3

Perbedaan rata-rata frekuensi BAB Bayi pada kelompok perlakuan dan kontrol

\begin{tabular}{cccc}
\hline \multirow{2}{*}{ Kelompok } & \multicolumn{2}{c}{ Mean Rank } & \multirow{2}{*}{ p-value } \\
\cline { 2 - 3 } & Negatif Rank & Positif Rank & 0,025 \\
Kelompok Perlakuan & 3,00 & 0,00 & 0,655 \\
Kelompok Kontrol & 3,00 & 3,00 & \\
\hline
\end{tabular}

\section{Pembahasan}

\section{Peningkatan berat badan bayi sebelum dan sesudah pijat bayi pada kelompok perlakuan dan} kontrol

Berdasarkan hasil penelitian diketahui bahwa ada pertambahan rata-rata berat badan pada kelompok perlakuan sebesar 521,8 gram, sedang pertambahan rata-rata berat badan pada kelompok kontrol sebesar 354,4 gram. Hasil penelitian ini sesuai dengan penelitian tentang efektifitas Massage Baby terhadap peningkatan berat badan bayi di BPS Bunda Kecamatan Mandiangin Koto Selayan Bukit Tinggi. Hasil penelitian menunjukkan berat badan bayi pada kelompok perlakuan dari sebelum dilakukan pemijatan sebesar 5.716,67 gram menjadi 6.366,67 gram dengan pemijatan bayi selama empat minggu dengan standar deviasi sebesar 665,833 (Sulung \& Gayatri, 2015).

Penelitian Triyana, Sukarja dan Utami (2012) tentang Pengaruh pijat bayi terhadap peningkatan berat badan bayi usia 3-6 bulan Wilayah kerja Puskesmas Denpasar Timur menunjukkan bahwa rata-rata berat badan bayi sebelum pijat bayi pada usia $3-<4$ bulan seberat 5423,08 gram dan setelah dilakukan pijat bayi seberat 5715,38. Pada usia 4-5 bulan dari rata-rata 6283,33 gram sebelum dilakukan pijat bayi meningkat menjadi 6754,55 gram setelah dilakukan pijat bayi, dan pada usia 5-6 bulan dari rata-rata 6516,67 gram sebelum dilakukan pijat bayi menjadi 6977,27 gram setelah dilakukan pijat bayi. Penelitian Sumini, Rosita dan Rahmadhani (2012) tentang pengaruh pijat bayi terhadap penambahan berat badan bayi 1-6 bulan di desa Kwangsen, Kecamatan Jiwan Madiun juga menunjukkan dari 30 responen 27 dilakukan pijat bayi dan 3 tidak dilakukan. Baik yang dilakukan pijat bayi yaitu 27 responden dan yang tidak dilakukan pijat bayi yaitu 3 responden semuanya (100\%) naik berat badannya.

\section{Lama waktu tidur sebelum dan sesudah pijat bayi pada kelompok perlakuan dan kontrol}

Hasil penelitian diketahui bahwa pertambahan rata-rata lama waktu tidur pada kelompok perlakuan sebesar 80,7 menit, sedangkan rata-rata waktu tidur bayi pada kelompok kontrol berkurang sebesar 53,9 menit. Hasil penelitian ini sejalan dengan penelitian Minarti dan Utami tahun 2012, tentang pengaruh pijat bayi terhadap kualitas tidur bayi usia 3-6 bulan di wilayah kerja Puskesmas Puskesmas II Denpasar Timur yang menyebutkan rata-rata kualitas tidur sebelum dilakukan pijat bayi sebesar 23,77 dan setelah dilakukan pijat bayi meningkat menjadi 30,83. Penelitian ini juga sesuai dengan penelitian Mardiana dan Martini tahun 2014 tentang pengaruh pijat bayi terhadap kualitas tidur bayi 3-6 bulan di Desa Munungrejo Kecamatan Ngibang Kabupaten Lamongan menunjukkan bahwa 
kualitas tidur bayi sebelum dilakukan pijat bayi selama 12,42 jam perhari dan meningkat menjadi 13,77 jam perhari setelah dilakukan pijat bayi, berarti kenaikan sebesar 1,29 jam perhari.

\section{Tingkat kelancaran buang air besar sebelum dan sesudah pijat bayi pada kelompok perlakuan dan kontrol}

Berdasarkan penelitian diketahui bahwa pada kelompok perlakuan sebelum dilakukan pelatihan dan pelaksanaan pijat bayi terdapat 5 orang bayi yang tidak normal dalam kelancaran BAB, sedangkan setelah dilakukan pelatihan dan pelaksanaan pijat bayi semua bayi normal dalam kelancaran BAB. Pada kelompok kontrol sebelum dilakukan pelatihan dan pelaksanaan pijat bayi terdapat 4 orang bayi yang tidak normal dalam kelancaran BAB, sedangkan setelah dilakukan pelatihan dan pelaksanaan pijat masih ada 3 orang bayi yang tidak normal dalam kelancaran BAB.

Penelitian ini sesuai dengan pendapat Subakti dan Anggraini (2008) yang menyatakan bahwa manfaat pijat bayi antara lain adalah meningkatkan gerak peristaltik untuk pencernaan. Sebuah studi di Korea menyatakan bahwa terapi pijat memiliki efek potensial pada peningkatan pertumbuhan fisik dan fungsi pencernaan pada bayi prematur. Studi dilakukan terhadap 10 orang kelompok eksperimen dan 10 orang kelompok kontrol (Hye Jeong Choi, 2015).

Menurut Widasari (2012), salah satu cara mengatasi sembelit pada bayi dengan cara pemijatan lembut di sekitar perut bayi dari pusat ke arah keluar dengan gerakan melingkar searah jarum jam. Pemijatan bisa menggunakan krim atau minyak pijat bayi yang dapat memudahkan tangan untuk melakukan pemijatan dengan lembut.

\section{Efek Pijat Bayi terhadap Peningkatan BB Bayi}

Berdasarkan hasil penelitian diketahui bahwa ada perbedaan rata-rata berat badan bayi sebelum dan sesudah dilakukan pemijatan pada kelompok perlakuan dengan $\mathrm{p}$ value 0,000 . Hasil penelitian ini sesuai dengan beberapa penelitian terdahulu tentang efek pijat bayi terhadap peningkatan berat badan bayi.

Hasil penelitian ini sejalan dengan penelitian T. Field \& Scafidi (1996 dan 1990) yang dikutip oleh Roesli (2011) bahwa terapi pijat memberikan efek positif secara fisik, antara lain kenaikan berat badan bayi dan peningkatan produksi air susu ibu (ASI). Pengamatan terhadap perubahan berat badan 20 bayi prematur setelah mendapat pijatan secara teratur. Bayi mengalami kenaikan berat badan 20 $47 \%$ per hari setelah dipijat $3 \times 15$ menit selama 10 hari. Pada bayi berusia $1-3$ bulan yang dipijat 15 menit dua kali seminggu selama enam minggu mengalami kenaikan berat badan lebih tinggi dari kelompok bayi yang tidak dipijat. Pemijatan merangang aktivitas nervus vagus. Penelitian Field dan Schanberg (1996) yang dikutip oleh Rusli (20011) menunjukkan bahwa pijat bayi meningkatkan tonus nervus vagus ( saraf kranialis ke-10) yang akan meningkatkan kadar enzim penyerapan gastrrin dan insulin. Meningkatnya kadar enzim penyerapan gastrin dan insulin maka penyerapan nutrien akan lebih bayak. Hal ini yang menyebabkan peningkatan berat badan bayi yang dipijat meningkat lebih banyak dari pada yang tidak dipijat.

Penelitian lain tentang pengaruh stimulasi pijat bayi terhadap peningkatan berat badan pada Bayi lahir cukup bulan menunjukkan bahwa pijat pada bayi oleh orang tuanya meningkatkan hubungan emosional antara orang tua dan bayi, meningkatkan berat badan, dan meningkatkan produksi ASI (Dewi dan Soetjiningsih, 2011). Hasil penelitian tentang efektifitas Massage Baby terhadap peningkatan berat badan bayi di BPS Bunda Kecamatan Mandiangin Koto Selayan Bukit Tinggi tahun 2014 menunjukkan ada peningkatan berat badan bayi secara bermakna pada usia 3-4 bulan dari sebelum dan setelah dilakukan pijat bayi selama 4 minggu dengan nilai $p=0,0001$ (Sulung dan Gayatri, 2015). Penelitian Triyana (2012) Sukarja dan Utami tentang Pengaruh pijat bayi terhadap peningkatan berat badan bayi usia 3-6 bulan Wilayah kerja Puskesmas Denpasar Timur juga 
mendapatkan hasil ada perbedaan yang bermakna peningkatan berat badan bayi sebelum dilakukan pemijatan dan sesudah pemijatan dengan nilai $p=0,000$. Penelitian Sumini, Rosita dan Rahmadhani (20012) tentang pengaruh pijat bayi terhadap penambahan berat badan bayi 1-6 bulan di desa Kwangsen, Kecamatan Jiwan Madiun juga menunjukkan ada perbedaan yang bermakna peningkatan berat badan bayi sebelum pemijatan dan sesudah pemijatan dengan nila nilai $\mathrm{p}=0,00$.

Penelitian lain yang dilakukan oleh Irva, Hasanah dan Worferst (2012) tentang Pengaruh terapi pijat terhadap kenaikan berat badan bayi menggunakan kelompok perlakuan dan kelompok kontrol di Puskesmas Harapan Raya Pekan Baru tahun 2014 menunjukkan ada perbedaan yang bermakna peningkatan berat badan bayi sebelum pemijatan dan sesudah pemijatan antara kelompok perlakuan dan kelompok kontrol dengan nilai $\mathrm{p}=0,01$.

Penelitian ini berbeda dengan penelitian Lee (2006) yang menyebutkan bahwa tidak ada perbedaan yang signifikan antara berat badan bayi sebelum dilakukan pemijatan dan setelah dilakukan pijat bayi selama 4 minggu pada kedua kelompok yaitu kelompok yang dipijat dan kelompok yang tidak dipijat. Perbedaan penelitian ini dengan penelitian Lee 2006 meliputi: Penelitian Lee 2006 jenis kelamin responden dikendalikan dan Ras renponden Korea/Indo, sedang penelitian ini jenis kelamin responden tidak dikendalikan dan Ras responden Jawa dan Lampung.

\section{Efek Pijat Bayi terhadap Peningkatan waktu tidur}

Hasil penelitian diketahui bahwa ada perbedaan rata-rata waktu tidur bayi sebelum dan sesudah dilakukan pemijatan pada kelompok perlakuan dengan $p$ value 0,000 . Pada kelompok kontrol juga ada perbedaan rata-rata waktu tidur bayi sebelum dan sesudah dilakukan pemijatan pada kelompok perlakuan dengan $\mathrm{p}$ value 0,030 .

Penelitian ini sesuai dengan pernyataan Roesli (2011), umumnya bayi yang dipijat tertidur lelap, sedang pada waktu bangun konsentrasinya akan lebih penuh. Menurut Maharani, (2009) manfat pijat bayi ditinjau dari dua segi yaitu bagi ibu dan bagi bayinya. Salah satu manfaat bagi bayi adalah membantu untuk bisa tidur nyenyak, meningkatkan fungsi sitem pencernaan, pernafasan, peredaran darah darah saraf dan kekebalan tubuh. Penelitian Mardiana dan Martini (2014) tentang Pengaruh pijat bayi terhadap kualitas tidur bayi 3-6 bulan di Desa Munungrejo Kecamatan Ngibang Kabupaten Lamongan mendapatkan ada pengaruh pijat bayi terhadap kualitas tidur bayi sebelum dilakukan pemijatan dengan sesudah dilakukan pemijatan. Penelitian lain tentang Pengaruh pijat bayi terhadap kualitas tidur bayi 3-6 bulan Rumah Sakit Keluarga Sehat Pati mendapatkan bahwa ada perbedaan yang bermakna kualitas tidur bayi yang dilakukan pemijatan dengan kualitas tidur bayi yang tidak dilakukan pemijatan nilai $\mathrm{p}=0,004$ (Pahlawanti, 2013). Penelitian ini juga sejalan dengan penelitian Minarti dan Utami (2012) tentang pengaruh pijat bayi terhadap kualitas tidur bayi usia 3-6 bulan di wilayah kerja Puskesmas Puskesmas II Denpasar Timur yang mendapatkan bahwa ada pengaruh pemberian pijat bayi terhadap kualitas tidur bayi usia $3-6$ bulan dengan nilai $p=0,000$.

Manfaat pijat bayi dapat mengurangi menangis, dan rewel, membantu tidur lebih damai (tenang) dan meringankan induser seperti sembelit. Menurut Direktur Touch Research Institute di University of Miami School of Medicine, ketika seorang bayi dipijat maka akan merangsang system saraf pusat yang memicu reaksi berantai sehingga otak menghasilkan serotonin yang lebih banyak, zat kimia lebih baik dan mengurangi kortisol hormon yang diekskresikan menanggapi stress sehingga bayi menjadi lebih santai dan tidur lebih nyenyak (Gottesman, 2009). Pijat bayi menyesuaikan sirkadian (hormon yang mengatur fase tidur dan bangun tidur) pada bayi yang dipijat menunjukkan isyarat kuat meningkatkan koordinasi sitem sirkadian berkembang dengan lingkungan seperti cahaya, kebisingan dan kegiatan (Surbakti dan Anggraini, 2008). 


\section{Efek Pijat Bayi terhadap Kelancaran frekuensi BAB}

Berdasarkan hasil penelitian diketahui bahwa ada perbedaan rata-rata frekuensi BAB bayi sebelum dan sesudah dilakukan pemijatan pada kelompok perlakuan dengan $\mathrm{p}$ value 0,025 . Penelitian ini sejalan dengan beberapa penelitian tentang tentang pengaruh pijat bayi terhadap kualitas tidur bayi. Penelitian ini sejalan dengan beberapa penelitian terdahulu tentang pengaruh pijat bayi terhadap frekuensi BAB pada bayi.

Penelitian ini sejalan dengan pendapat Subakti dan Anggraini manfaat pijat bayi antara lain adalah meningkatkan gerak peristaltik untuk pencernaan. Peristaltik menurut Thibadeau dan Patton yang dikutip Subakti dan anggraini semacam gelombang dan kontraksi teratur menuju lambung (saluran pencernaan) yang menggerakkan bahan makanan agar berproses dfalam saluran pencernaan makanan.

Sebuah studi di Korea menyatakan bahwa terapi pijat memiliki efek potensial pada peningkatan pertumbuhan fisik dan fungsi pencernaan pada bayi prematur. Studi dilakukan terhadap 10 orang kelompok eksperimen dan 10 orang kelompok kontrol (HyeJeong Choi, 2015). Penelitian Novianti (2010) tentang Pengaruh Terapi Pijat dalam Penurunan Frekuensi BAB dan Tingkat Dehidrasi pada Anak Usia 0-2 Tahun dengan Diare di RSUD Cibabat Cimahi tahun 2010 terdapat pengaruh yang signifikan pada kelompok responden yang diberi terapi pijat dalam penurunan frekuensi buang air besar dan penurunan tingkatdehidrasi dengan nilai $\mathrm{p}=0,000$.

Menurut Widasari (2012), salah satu cara mengatasi sembelit pada bayi dengan cara pemijatan lembut di sekitar perut bayi dari pusat kearah keluar dengan gerakan melingkar searah jarum jam. Pemijatan bisa menggunakan krim atau minyak pijat bayi yang dapat memudahkan tangan untuk melakukan pemijatan dengan lembut.

\section{Simpulan dan Saran}

Simpulan hasil penelitian pijat bayi efektif untuk meningkatkan rata-rata berat badan bayi, rata-rata waktu tidur bayi, dan rata-rata frekuensi BAB bayi. Upaya sosialiasi perlu ditingkatkan untuk melakukan program pijat bayi, sehingga bayi dilakukan rutin pemijatan baik oleh ibu maupun dengan mendatangi Bidan.

\section{Referensi}

Dewi N. N dan Soetjiningsih, 2011, Pengaruh Stimulasi Pijat Bayi Terhadap Peningkatan Berat Badan pada Bayi Lahir Cukup Bulan, Tesis, Universitas Gadjah Mada, Yogyakarta.

Dinkes Provinsi Lampung. 2013. Profil Kesehatan Provinsi Lampung Tahun 2012. Bandar Lampung.

Gottesman N. 2009. The Benefits of Baby Massage, Parents Magazine, May 2009, http://www.Paren.com/baby/care/newborn/baby-massage

HyeJeong Choi. at all. 2015.The effects of massage therapy on physical growth and gastrointestinal function in premature infants. A pilot study. SAGE Journals. Journal of Child Health Care. August 2015.

Irva T.S, Hasanah O dan Worferst R. 2014. Pengaruh terapi pijat terhadap Pemingkatan Berat Badan Bayi. Jurnal Online Mahasiswa PSIK Universitas Riau Vol I No 2 Oktober 2014. http://jom.unri.ac.id, diakses tanggal 2 Nopember 2015

Lemeshow. 2000. Adequacy of Sample Size in Health Studies. USA: John Wiley \& Sons Ltd. WHO

Lee H.K. 2006. The effects of infant massage on weight, height, and mother-infant interaction, Journal of Korean Academy of Nursing. Vol. 36 (8). pp. 1331-1339

Maharani. Sabrina. 2009. Pijat dan Senam Sehat Untuk Bayi. Jogjakarta: Katahati

Mardiana L dan Martini D.O. 2014. Pengaruh pijat bayi terhadap kualitas tidur bayi 3-6 bulan di Desa Munungrejo Kecamatan Ngibang Kabupaten Lamongan. Jurnal Surya. Volume 2 No. XVIII, Juni 2014 
Minarti N.M.A.M, Utami, K.C. 2012. Pengaruh Pijat Bayi Terhadap Kualitas Tidur Bayi Usia 3-6 Bulandi Wilayah Kerja Puskesmas II Denpasar Timur Tahun 2012. Bali: Program StudiI lmu Keperawatan Fakultas Kedokteran Universitas Udayana

Novianti S.E. 2010. Pengaruh Terapi Pijat dalam Penurunan Frekuensi BAB dan Tingkat Dehidrasi pada Anak Usia 0-2 Tahun dengan Diaredi RSUD Cibabat Cimahi. Cimahi: STIKES A. Yani Cimahi

Pahlawanti Z,H. 2013. Pengaruh Pijat dengan Lama Tidur Bayi Usia 3-6 Bulan di Rumah Sakit Keluarga Sehat Pati. UNIMUS Digital Library, Universitas Semarang.

Pratyahara, D. 2012. Keajaiban Terapi Sentuh Untuk Bayi Anda. Jakarta: PT Buku Kita

Puskesmas Punggur, 2015, Laporan Bulanan Puskesmas Punggur Tahun 2015, Punggur

Roesli, U. 2011. Pedoman Pijat Bayi. Jakarta: PT. Trubus Agriwidya

Subakti, Y dan Anggraini. 2008. Keajaiban pijat bayi dan balita. Jakarta: PT. Wahyu Medika

Sulung N dan Gayatri A.C.D. 2015. Efektifitas massage baby terhadap peningkatan berat badan bayi di BPS Bunda Kecamatan Mandiangin Koto Selayan Bukit Tinggi tahun 2014, Menara Ilmu Vol. IX Jilid 2 No 57. Bukit Tinggi.

Sumini, Rosita A, dan Rahmadhani S.A. 2012. Pengaruh Pijat Bayi terhadap Pertambahan Berat Badan Bayi di Desa Kwangsen Kecamatan Jiwan Kabupaten Madiun. Madiun. Jawa Timur.

Triyana KY, I Made Sukarja dan Kadek Utami. 2012. Pengaruh Pijat Bayi Terhadap Peningkatan Berat Badan Bayi Usia 3-6 Bulan di Wilayah Kerja Puskesmas II DenpasarTimur. Program studi Ilmu Keperawatan Fakultas Kedokteran Universitas Udayana

Widasari S. 2012. Susah Buang air Besar (BAB) Penyebab dan Cara Mengatasi, Informasitips.com. Diakses tanggal 2 Nopember 2015 